\title{
Laura-Yvonne PATIÑO-GASS
}

Universidad Carlos III de Madrid. Spain.100391711@alumnos.uc3m.es

\section{Dra. Patricia GONZÁLEZ-ALDEA}

Universidad Carlos III de Madrid. Spain. patricia.gonzalez.aldea@uc3m.es

\section{Armed conflicts and gender perspective: Media representation of girls' soldiers \\ Conflictos armados y perspectiva de género: Representación mediática de las niñas soldado}

Dates | Received: 14/02/2020 - Reviewed: 08/04/2020 - In press: 11/05/2020 - Published: 01/01/2021

\begin{abstract}
The United Nations estimates 300,000 child soldiers in conflicts around the world. According to the UN, in 2018, recruitment of child soldiers increased in several countries, such as the Democratic Republic of Congo and the Central African Republic. Recruitment activities attained an alarming level in South Sudan and Somalia. However, academic literature and media have not devoted enough coverage to this critical issue; in particular with regard to child soldiers' media coverage from a gender perspective. This project sought to study girl soldiers' representation within the frame of two African conflicts: Southern Sudan and the Central African Republic. The study entailed a qualitative analysis of these conflicts in two quality newspapers: The Guardian and Le Monde from 2011 to 2017. The results showed that the discursive presence of girl soldiers in the articles analysed is very limited in comparison to that of boy soldiers. Girl soldiers are mainly represented in as victims of sexual abuse rather that in the role of supposedly male combatants. In addition, minimal coverage relating to positive news, such as girls' rehabilitation processes, was also highlighted.
\end{abstract}

\section{Keywords}

Girl soldiers; child soldiers; armed conflict; gender perspective; media coverage; media representation

\section{Resumen}

Naciones Unidas estima que globalmente hay 300.000 niños y niñas soldados en conflictos. Según dicha organización en 2018 el reclutamiento de niños y niñas aumentó en varios países como en la República Centroafricana y República Democrática de Congo, y alcanzó cifras alarmantes en Sudán del Sur y Somalia. Sin embargo, ni la literatura académica ni la cobertura mediática han dedicado espacio suficiente a esta grave problemática, en especial cuando se trata de representar en los medios la realidad de las niñas soldado desde el enfoque de género. Esta investigación aborda el estudio de caso de la representación de las niñas soldado en dos conflictos africanos: Sudán del Sur y República Centroafricana. Para ello hace un análisis cualitativo de la cobertura de dichos conflictos en dos diarios considerados quality press: The Guardian y Le Monde, entre 2011-2017. Los resultados mostraron que la presencia discursiva de niñas soldado en los artículos analizados es muy limitada en comparación a los niños soldados, con un encuadre predominante de víctimas de abusos sexuales, y no en el rol de combatientes supuestamente masculino, y sin apenas cobertura de noticias positivas como los procesos de rehabilitación de estas niñas.

\section{Palabras clave}

Niñas soldado; niños soldado; conflictos armados; perspectiva de género; cobertura mediática; representación mediática 


\section{Introduction}

One day men came to our house with canes, my parents managed to escape but they took me, my sister and my brother," one girl told us. "They [SSNLM] took us to Birisi [South-Western South Sudan] where we immediately had to participate... If you didn't learn fast they would cane you (Child Soldiers International, 2018).

This is the story of a former girl soldier from South Sudan. Her story is not that unlike from many other children around the world. According to Leila Zerrogui, former Special Representative of the Secretary-General for Children and Armed Conflict, in the world there are 300,000 child soldiers (United Nations Youth, 2015). This amount is only an estimate due to how difficult it is to obtain a precise number. In the report published in 2019, which includes the 2018 January-December period, the UN reported that severe violations have increased. These severe violations are seen in the recruitment of children, murder, mutilations, sexual violence, and kidnappings. More than 24,000 serious violations of children's rights have been denounced among non-state armed groups and governmental forces. The recruitment of children has increased particularly in many countries such as: the Central African Republic, the Democratic Republic of Congo, South Sudan, and Somalia (United Nations, 2018).

Even though both boys and girls are recruited, there are limited bibliographical resources about girls' participation in armed conflicts. According to Böhmelt and Haer (2018), among the different non-state groups that recruit minors, girl soldiers can be up to $40 \%$ of the children recruited in recent conflicts in Africa. This is not only a current phenomenon: "Few historical accounts exist of girls' participation in warfare. Yet, it is inaccurate to imagine that girls' engagement in fighting forces and groups is a 20th and 21 st century phenomenon" (Mazurana, McKay, Carlson \& Kasper, 2002: 101).

So far, scholars have studied the phenomenon of child soldiers with a general perspective (McKay, 1998; Rosen, 2005; Honwana, 2006), but there has been limited research focused on gender. Academic literature shows that gender is invisible in this subject matter. Such as Myriam Denov (2012) highlights, the media has only portrayed these girls in the context of silent victims, as 'wives', or victims of sexual slavery.

Despite the fact that the representation of girl soldiers as victims helps give this problem visibility, it can result in a double victimization as it gives more attention to the victims instead of condemning their victimizers. The media has portrayed boy soldiers posing alongside the well-known AK-47 assault rifles. Even though there are girls in fighting roles, they are rarely depicted carrying weapons. This as well as other media images join three main representations of child soldiers in the media, according to Denov (2012): "dangerous and disorderly, the hapless victim and the hero".

Considering that news in the media build up public discourse and has an impact on policy making (Gamson and Modigliani, 1989; Andsager; 2000; Entman, 2004) an adequate gender approach can prove to be especially relevant. Thus, to understand how the media portrays girl soldiers is crucial to understand popular awareness regarding these girls. It's in this pursuit that the objective of this paper is to analyse children from a general perspective and girls in particular, within two armed conflicts in Africa, where the use of girl soldiers is high: South Sudan and the Central African Republic.

When Sudan obtained its independence from Great Britain in 1952, the region was trifled with many internal wars between what is now Sudan and South Sudan. The northern part began to dominate politically over the whole region, during the decolonisation process in 1955. In the following years, the country suffered political, economic, and social instability due to the continuous fighting between the North and the South, up until 2005 (Thomas, 2018). That year, both sides signed a treaty that marked the Northern and Southern borders. The referendum was welcomed in 2011 , to determine the definite separation between North and South Sudan. Just after the very foundation of this new State, a civil war began which lead to numerous deaths and the recruitment of child soldiers. According to UNICEF, since 2013 a near estimate of 17,000 child soldiers have been recruited in South Sudan.

The Central African Republic obtained its independence from the French Republic on December 1st, 1960. Since then, military coups and political instability have been a constant part of the political situation in this republic. In 2005, elections were held and François Bozizé was elected President. A new crisis hit the country in 2012 with the rise of the rebel group Séléka, rivalling the Bozizé regime, which later lead to the president's resignation. In 2013, a civil war broke out that startled the nation. The United Nations estimates that around 10,000 child soldiers were recruited in the first years since the beginning of the conflict.

Despite the horrifying figures, most of what has happened during these two armed conflicts has remained invisible in the media, such as many other forgotten conflicts. Nonetheless, "The limiting of subjects by the media's agenda, state interests, nor the vicinity of the matter ever explain enough. But above all, they don't justify in any way, the invisibility of certain conflicts in the media." (González-Aldea, 2014: 119). 
The main objective of this paper is to contribute to help give visibility to girl soldiers, through the critical analysis of their representation in the media. The specific objectives are the following:

- To analyse the media's discourse in the representation and role of girl soldiers in the armed conflicts of South Sudan and the Central African Republic.

- To reveal the double victimization in media coverage, as the press gives more relevance to victimhood situations, than to condemning the perpetrators of violence towards girls. In addition, the media fails to inform about recovery programs for these girls; by this, it perpetuates gender roles.

The initial hypothesis considers that a gender bias against girls exists in the discursive coverage of conflicts that use child soldiers. For the most part, when the media mentions child soldiers they only refer to boys. They ignore the participation of girl soldiers in armed conflicts. The second hypothesis affirms that when girl soldiers are mentioned they are merely represented as sex slaves and not in combating roles, which are usually masculine. The third hypothesis points out that there is limited coverage regarding how difficult it is for these girl soldiers to recover due to the gender inequality, which is perpetuated even more due to their lack of acknowledgement.

\section{Armed conflicts and boy and girl soldiers}

\subsection{Child Soldiers concept}

According to UNICEF's Paris Principles and Guidelines on children associated in Armed Forces or Armed Groups (2007: 7), "Child Soldier" is defined as:

A child associated with an armed force or armed group" refers to any person below 18 years of age who is or who has been recruited or used by an armed force or armed group in any capacity, including but not limited to children, boys and girls, used as fighters, cooks, porters, messengers, spies or for sexual purposes. It does not only refer to a child who is taking or has taken a direct part in hostilities.

This concept is relevant as it indicates a guideline regarding a focus on the age in which individuals are still considered children. It also details the number of functions that can be carried out by children.

Nevertheless, there are different perceptions in reference to the beginning of adulthood according to social and cultural context (Denov, 2010), since childhood is a social construct (Honwana, 2006). In middle class families, parents offer economical support until their children can work for themselves. While in Angola, the Tchokwé identify their children by the role they adopt and the tasks they perform. "For example, tchitutas are boys and girls around the age of five or seven, whose role is to fetch water and tobacco for the elders and take messages to neighbours" (Honwana, 2006: 42).

Meanwhile, the use of the term "soldier" is often used for individuals that receive military training within military institutions (Honwana, 2006). "While the term 'child soldier' encapsulates the paradox of children's involvement in wartime violence, particularly the blurring of constructed notions of childhood 'innocence' with the brutality and violence of war" (Denov, 2010: 2).

Since the issue of child soldiers has been in public debate, the dominant discourse and narrative has been limited. Mainly, child soldiers have been assigned an identity and described as the threat that they represent to social order (Macmillan, 2009)

One of the first international documents to address the issue of children in armed conflicts was the "Convention on Children's Rights" in 1989. The treaty has been ratified by 192 of the 193 members of the UN. Only the United States continues to refrain from signing.

Nearly a decade later, Machel Graça published a paper before the General Assembly of the United Nations (1996) on the impact that armed conflicts have on children. The main objective of this study was to begin offering follow-up reports on children in areas of armed conflicts, and offer them support. This study was the first of its kind in the UN with a gender approach. Special attention was placed on problems that women and girls faced in armed conflicts (MCKay, 1998). This can be found in section C, titled: "Ending gender-based violence and sexual exploitation".

In the year 2007, in Paris, the French Government and UNICEF organized a conference to liberate children from war. After this event, the "Paris commitments and the Paris principles" determined a group of guidelines for children in armed conflicts. In this conference, child soldiers were considered a minor that serves in an armed conflict, regardless if they are with official state armed forces or not. In the "Principles and Guidelines on Children Associated to Armed Forces or Armed Groups" the tasks in which boys or girls 
take part in to be qualified as child soldiers are described as: any type of function, including, although not only limited to, boys and girls are used as fighters, cooks, porters, messengers, spies, or for sexual purposes." (Unicef, 2007: 7). Soldier boys and girls can therefore actively participate in combat, or in support roles.

\subsection{Girl Soldiers in Armed Conflicts}

The fact that girl soldiers represent nearly up to $40 \%$ of non-state armed groups (Böhmelt \& Haer, 2018) is often invisible. When presenting only boys, the role of girls in armed conflicts becomes invisible.

The role of girls also becomes invisible due to cultural differences that define who is considered a girl and who is a woman. As McKay (2005) states, in some African countries with no western notion of a girls' adolescence, girls are considered to be women after certain initiation rites. Whereas in western culture they are still considered to be girls until they are 18 years old. This is why there is no consensus in international agreements to define 18 years of age as the initiation of adulthood for both men and women.

Usually, when researchers discuss the issue of child fighters, they use the term child soldiers, which in English includes boys as well as girls. Nonetheless, the examples they use almost always portray boys' experience, which leaves the experiences of girls behind (Spellings, 2008). The few times in which they are represented as McMillan (2009) states, the portrayal of these girls is dehumanizing, in the sense that it depicts them as subjects that suffer 'degradation, humiliation, injuries, and torture' instead of being subjects that act under very unequal power relations.

It is very important to study about girl soldiers for several reasons:

- Firstly, from a socio-political standpoint, girls will eventually become adults and shall impact their communities (Spelling, 2008).

- Secondly, it is linked to their gender roles. Women are usually responsible for children's socialization (Machel, 2001). Girls that have participated in conflicts alongside armed groups get used to having aggressive attitudes that can be passed on to their children (Spelling, 2008).

- Thirdly, to mark the differences that girl's experiment as soldiers in comparison to boys. Girls usually take on the same combat duties that boys do, but non-state armed groups usually uphold gender differences. For which, in their majority, women and girls are in charge of doing the domestic work, such as: cooking, child care, washing clothes (Brownell \& Praetorius, 2017). In addition to having more duties, the inequality between girls and boys is marked by receiving less food, as well as receiving scarce medical attention (Mazurana \& McKay 2001).

In the 2018 United Nations report (which refers to 2017) the recruitment of girls was confirmed in other countries, such as: Central African Republic, Colombia, the Democratic Republic of Congo, Iraq, Mali, Myanmar, South Sudan, Sudan, Syrian Arab Republic, Nigeria, and the Philippines. The number of girls recruited differs by county and armed group. For example, in South Sudan 1.221 children recruited were confirmed of whom 164 were girls, a significantly high number. In the Central African Republic, the number of verified cases of child recruitment increased fourfold compared to the previous report. 299 cases were verified, of which, 106 were boys, and 103 girls (United Nations, General Assembly, A/72/865-S/2018/465, 2018). A year later, according to the 2019 report (which refers to 2018), the number of children recruited in South Sudan decreased to 453, of which 365 were boys, and 88 girls; in the Central African Republic 137 minors were recruited and used, of which 95 were boys, and 42 girls (United Nations, General Assembly, A/73/907-S/2019/509, 2019).

Age differences in the recruitment of girls vary. In the $2018 \mathrm{UN}$ report, there are cases of recruitment of 8 year-old girls in the Central African Republic, while 16 and 17 year-old girls were recruited in the Democratic Republic of Congo. Nonetheless, Myriam Denov (2010) in her book titled, "Child Soldiers", interviewed former child soldiers and found that some girls were recruited as young as 4 years old and were soldiers up to 8 years more.

Gathering information about the tasks that are detailed in UN General Assembly Report (2018:14), the following are: carriers, combatants, informants, spies, cooks, combatant's wives, sexual abuse and exploitation, forced farm work, suicide terrorists, explosive artefact manufacturing, guards.

Although many similarities may exist between boys and girls, there are many differences that justify studying the phenomenon of child soldiers from a gender perspective (Fox, 2004):

- Boys and girls usually have similar experiences in armed groups, except for the abuse committed against girls. 
- The experiences of girls are more severe due to sexism and misogyny. In armed conflicts this is intensified by the violence perpetuated towards girls and women, from men and boys, with great emphasis on sexual violence.

Despite the importance of highlighting the sexual violence that many women face in war, to focus only on that aspect can hinder the understanding of the experiences and the roles that girls carry out in non-state armed groups (Honwana, 2006).

Girls cease to be considered soldiers when they no longer form part of the armed group. This happens due to several reasons: they can escape, the war may end, or they are rescued by the country's armed forces, or by Non-Governmental Organizations. For instance, the UN has a peace program in alliance with national institutions to implement Disarmament, the Demobilization, and the Reintegration (DDR). The DDR program is one of the many tools that help access a more lasting stability and peace (Baas, 2011).

The DDR process can take place without the UN taking the initiative. The DDR has three main objectives. First, to collect and destroy all the weapons, second to demobilize and third, to reinsert ex combatants (Coulter, Perrson \& Utas, 2008) in the civilian sphere. Those enrolled in DDR programs often receive financial assistance, vocational classes with materials (Coulter et al., 2008). DDR programs usually begin when conflicts have ceased for the adult members of different armed groups, while the programs for children can be established during a conflict.

However, gender discrimination in war-affected countries remains high. In a study by Dyan Mazurana (2005) for the Geneva Call, it was noted that most women and girls associated with armed opposition groups in Africa do not participate in official DDR programs. They found two main reasons why this occurs: first, corruption among commanders, which are men that wish to obtain benefits for themselves and their families, and second, the biased definition of the term "combatant".

Each program is different according to each country and conflict. There is also a different approach for former adult soldiers and for child soldiers. For example, the DDR program for the Central African Republic is based on a community plan. The purpose of this program is to fortify and restore a protected environment for former child soldiers. In this program, there is also an approach towards recruitment prevention (Cotorcea, 2017).

Some DDR programs have more success than others. For example, in Sudan, it wasn't effective. The program failed to secure employment, nor could it secure a sound psychological treatment, nor a healthy social environment for social reinsertion (UN OSAA, 2007, p.5, ob.cit. Carlsen, 2013).

\subsection{Media Representation of Boy/Girl Soldiers}

There are not many studies (Rosen, 2005; McKay, 2005; Spellings, 2008; Macmillan, 2009; Denov, 2012; Tassava, 2017) that analyse how the media represents child soldiers, particularly girl soldiers. However, the media construct the news in a certain way to give it meaning (McCombs \& Shaw, 1993). This is called framing theory. Framing is the process in which certain aspects of a perceived reality are selected and highlighted to enhance the evaluation and interpretation of this reality (Entman, 2004). The frames can be considered as the social representation in which a subject is understood. The reader cannot obtain firsthand information regarding child soldiers, so their perception of this subject basically depends on the frame given by the media.

The portrayal of child soldiers is varied, but almost always stereotyped. They have been stigmatized as dangerous, monstrous, and barbaric (Rosen, 2005; Macmillan, 2009). They are seen as children that have faced violence almost throughout their whole lives; hence they are prone to repeat the same patterns.

Child soldiers are also represented like victims, since they have been forced to participate in the violence of undemocratic regimes (Rosen, 2005; Macmillan, 2009).

Jessica Tasava (2017) analysed five Hollywood films and five documentaries to explore how child soldiers are portrayed and she found gender biases, considering how inadequately the experiences of girl soldiers were described.

Various researchers (McKay, 2005; Spellings, 2008; Denov, 2010) have described how girl soldiers are forced to marry their peers and commanders within armed groups, becoming so-called "Bush wives". Tassava (2017) only found this representation in one movie and documentary that she analysed. "Showing captive wives shown in $20 \%$ of films about child soldiers does not enable audience members to truly understand the experiences of female child soldiers" (Tassava, 2017: 168). In the five movies and documentaries only one female character is found fighting, which is an alleged masculine role. 
According to Myriam Denov (2012), the media simplified the subject matter of child soldiers and they framed it in three categories; "Dangerous and Disorderly", "Hapless Victim", and "Heroes".

- $\quad$ "Dangerous and Disorderly" refers to the aggressive qualifiers assigned to boy soldiers, not only in a violent context of war, but as in incorporated behaviours, attitudes that corrupt a child's innocence. "The images of boy soldiers have been used to broadcast the horrors of a corrupted childhood ridden from its 'natural' frail and pure innocence". (Denov, 2012: 282). These cliché descriptions of boy soldiers deepen stereotypes, according to Macmillan (2009), in highlighting the 'superior' morality of the North in relation with the South" (ob.cit. Denov, 2012).

- "The hapless victim" creates a narrative of children as victims incapable of making decisions. As Denov (2012) suggests, it is a vulnerable description that evokes sympathy, it can also become condescending and dehumanize children. This dis-empowers them and removes any decision that the children may have over their decisions. In the specific case of girl soldiers, the media almost always portrays them as victims of sexual abuse (Denov, 2012).

- "The hero" frame can be seen when child soldiers are presented as survivors of extreme violence. They are heroes because they survived these dangerous situations. "These youth have been portrayed as brave survivors of extreme violence who have overcome great adversity and ultimately, despite their participation in violence, have been redeemed" (Denov,2012: 283).

Based on the descriptions that Denov (2010: 8) collected, child soldiers are considered "traumatized children", "with fear". However, other research (Wessels, 2006; Blattman \& Annan, 2010; Ensor, 2012) shows that former child soldiers are psychologically stronger than adults, they forget sooner and can rehabilitate themselves better.

\section{Methodology}

The method used has been critical analysis of discourse (Van Dijk, 2008) to determine how girl soldiers are represented. This methodology has been developed among others by Fairclough (1992), Van Dijk (1997) and Wodak \& Meyer (2001). Critical discourse analysis is based on the principle that language is a social practice that not only serves to communicate, but also to define a society (Fairclough, 2001, ob.cit. Solman \& Henderson, 2019).

According to the Van Dijk model (2008), the discursive context of the selected news should be taken into account first because: "I consider contexts to be participant constructs or subjective definitions of interactional or communicative situations" (Van Dijk, 2008:16).

After that, the analysis and subsequent comparison of the media representation of soldier boys and girls in the two chosen conflicts was carried out. As categories for discourse analysis, the classification of Myriam Denov (2012) already mentioned in the previous section, was followed. The author found that the media simplifies the issue of child soldiers and fits them into three categories:

- Dangerous and disorderly (carry out murders, burn down places, fight, etc.)

- Hapless victim (object of sexual assault, kidnapping, etc.)

- Heroes (former child soldiers who write books, speak on behalf of child soldiers, etc.)

To frame our three categories in our media analysis, we focused on the following aspects of news content:

- The hapless victim: Forced recruitment, drug addiction, traumatized children, enlisted due to family pressure / orphans, victims of sexual abuse, forced to carry unwanted pregnancies, combatants' spouses, "factories" of child soldiers, domestic work, forced marriages, rape, sexually transmitted diseases, death, abortions, forgotten in DDR programs.

- Dangerous and Disorderly: combatants, description of atrocious acts committed, description of used weapons, cannot be rehabilitated.

- $\quad$ The hero participates in international trials, giving a voice to child soldiers.

The content of all the selected articles was analysed and collected in a table where the frame of each article belonged to one, two or even the three categories according to the different aspects mentioned above. Then citations or fragments were extracted showing such approaches.

This study showed the news of 2 international newspapers The Guardian (United Kingdom) and Le Monde (France), with worldwide recognition for being considered quality newspapers (Sparks \& Campbell, 1987. 
ob.cit. Quian and Elías, 2018). These two newspapers were chosen taking into account they were the last colonizing countries of the object of study: South Sudan and the Central African Republic. The United Kingdom was the last European country to influence Sudan, while France was the colonizing country of the Central African Republic. These are also wars forgotten by most Western media and coverage has been more extensive by the media of the former colonizing countries.

A seven-year longitudinal analysis was carried out. The period of time in which the news was analysed ranged from January 1, 2011 to December 31, 2017.

Regarding the chosen dates, the starting date of 2011 was chosen due to the fact that South Sudan obtained independence from Sudan in 2011. The referendum took place between January 9 and 15 and on July 9, independence was officially declared. However, in December 2013 a new conflict arose in the young State. Finally, a peace agreement was signed to end the war in 2018 . While in the Central African Republic, the last conflict unleashed in 2012, until the beginning of 2019 when a peace agreement was signed between the parties involved. Nevertheless, it was decided to search the news from January 2011 to have the same search trajectory in the two case studies.

Regarding the final date of 2017, it was chosen due to a certain improvement in the evolution of said conflicts in 2018 that reduced the recruitment of child soldiers, according to the figures obtained in the reports provided by the United Nations in the same time frame. In South Sudan, recruited girls dropped by about half, from 164 to 88, and in the Central African Republic from 103 to 42.

It was written in the Google search engine site: theguardian.com "Child Soldiers" so Google would only show the news published in The Guardian newspaper that had those words on the selected period of time. While site:lemonade.fr "Enfants Soldats" was also written in the Google site search engine for the Central African Republic on the site Lemonde.fr.

A total of 409 articles were found of which 202 were in The Guardian and 207 in Le Monde. The articles were then organized based on the date of publication. It was decided to randomly choose 1 article out of 5 to analysed the coverage longitudinally.

The final sample was 81 articles: 40 from The Guardian and 41 from Le Monde newspaper.

Table 1: Random dates analysed for the final sample

\begin{tabular}{llll|llll}
\multicolumn{5}{c}{ The Guardian } & \multicolumn{4}{c}{ Le Monde } \\
\hline $27 / 06 / 2011$ & $23 / 02 / 2013$ & $03 / 01 / 2015$ & $10 / 06 / 2016$ & $01 / 03 / 2011$ & $10 / 05 / 2013$ & $08 / 05 / 2015$ & $29 / 06 / 2016$ \\
$19 / 09 / 2011$ & $19 / 03 / 2013$ & $22 / 02 / 2015$ & $16 / 07 / 2016$ & $27 / 04 / 2011$ & $19 / 06 / 2013$ & $15 / 05 / 2015$ & $24 / 10 / 2016$ \\
$08 / 03 / 2012$ & $23 / 04 / 2013$ & $29 / 04 / 2015$ & $30 / 08 / 2016$ & $11 / 10 / 2011$ & $18 / 09 / 2013$ & $24 / 07 / 2015$ & $06 / 12 / 2016$ \\
$10 / 03 / 2012$ & $17 / 07 / 2013$ & $02 / 08 / 2015$ & $25 / 10 / 2016$ & $12 / 02 / 2012$ & $03 / 10 / 2013$ & $24 / 08 / 2015$ & $16 / 02 / 2017$ \\
$14 / 03 / 2012$ & $04 / 10 / 2013$ & $28 / 09 / 2015$ & $06 / 02 / 2017$ & $13 / 03 / 2012$ & $21 / 11 / 2013$ & $03 / 09 / 2015$ & $31 / 03 / 2017$ \\
$16 / 03 / 2012$ & $05 / 12 / 2013$ & $10 / 12 / 2015$ & $30 / 04 / 2017$ & $10 / 07 / 2012$ & $20 / 05 / 2014$ & $22 / 10 / 2015$ & $16 / 05 / 2017$ \\
$14 / 04 / 2012$ & $14 / 01 / 2014$ & $03 / 02 / 2016$ & $27 / 06 / 2017$ & $06 / 11 / 2012$ & $09 / 06 / 2014$ & $02 / 11 / 2015$ & $23 / 06 / 2017$ \\
$26 / 04 / 2012$ & $29 / 05 / 2014$ & $12 / 02 / 2016$ & $30 / 08 / 2017$ & $27 / 11 / 2012$ & $27 / 09 / 2014$ & $21 / 01 / 2016$ & $05 / 07 / 2017$ \\
$04 / 06 / 2012$ & $31 / 07 / 2014$ & $02 / 04 / 2016$ & $04 / 10 / 2017$ & $04 / 01 / 2013$ & $18 / 12 / 2014$ & $25 / 03 / 2016$ & $15 / 09 / 2017$ \\
$08 / 10 / 2012$ & $07 / 10 / 2014$ & $19 / 05 / 2016$ & $29 / 11 / 2017$ & $27 / 03 / 2013$ & $07 / 03 / 2015$ & $13 / 05 / 2016$ & $22 / 11 / 2017$ \\
& \multicolumn{7}{c}{ Source: Author created }
\end{tabular}

In each article by Le Monde and The Guardian, one, two or three of the frames defined by Denov were found depending on the context.

\section{Results}

Then, taking into account the context of the discourse that normalizes violence against child soldiers, we analyse the media representations of boy and girl soldiers in South Sudan (The Guardian) and Central African Republic (Le Monde).

\subsection{Representation of child soldiers}

It should be clarified that different frames of child soldiers could be found at the same time in the same article. Up to 91 occasions, features of one of the 3 frames representing child soldiers were found in the articles. And at the same time, more than one characteristic can be found in the same article and in a single frame. 


\subsubsection{The hapless victim}

"The hapless victim" is the most common frame in which the two newspapers, The Guardian and Le Monde, characterize child soldiers (victims of sexual assault, recruitment,), which appear in $59(72.83 \%)$ of the 81 articles.

\section{Chart 1. Characteristics in the frame of the hapless victim (boys)}

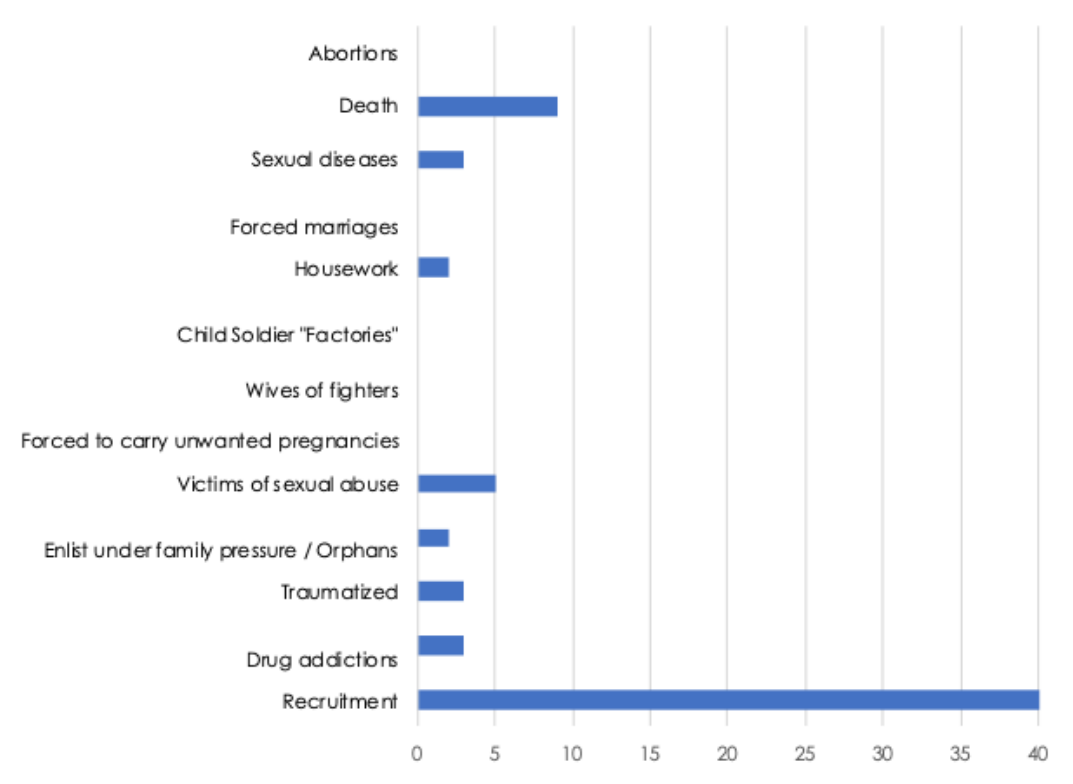

Source: Author created

The Guardian (February 22, 2015) reports that 89 children were abducted in South Sudan in February 2015. "Armed soldiers surrounded Wau Shilluk, a village near Malakal, and went house to house searching for boys and taking them away by force". It is unknown which one of the two-armed groups is responsible for the kidnapping.

Le Monde (September 14, 2013) highlights that the representative of the Central African Republic, Charles Armel Doubane, condemn the recruitment of child soldiers (by the armed group Séléka) in the United Nations Security Council.

In countries where there is political instability, such as in the Central African Republic, minors are more likely to be recruited by state and non-state armed groups. In situations of critical instability there may even be cases in which it is the troops of the allied countries who commit civilian abuse, as reported by The Guardian (April 23, 2015) in the case of the French militia in the Central African Republic. "The French troops sent to protect the tens of thousands displaced by the cycle of violence stand accused of exploiting the lawlessness engulfing CAR to engage in brutality themselves" (Smith, 2015).

The media also portrays children as victims of drug addictions and sexually transmitted diseases (STDs) due to their time in captivity. The Guardian (April 12, 2012) reports that: "Many suffer from drug addiction or diseases, including HIV. Others have been victims of sexual violence" (IRIN, 2012). Children can also be sexually abused by perpetrators, which in addition to trauma can have health implications, due to STDs. "Both male and female child soldiers are often sexually abused and are at high risk of contracting sexually transmitted diseases" (The Guardian, June 27, 2011).

The trauma experienced by children who suffer the aforementioned acts is still present even when they return to civilian life, and the lack of support from their communities does not help. The stigma of being "child soldiers" haunts them in their lives as civilians. Le Monde (February 12, 2012) reports: "Traumatized by the experience they lived through, the child soldiers once demobilized suffer when they return to a normal life" (January, 2012).

In order to learn how to live within a non-state armed group, child soldiers are abused by their peers and commanders and can be killed if they try to escape, which was the case of Congolese commander 
Ntaganda. The Guardian (June 4, 2012) reports "some recruits were summarily executed on the orders of Ntaganda's forces when they tried to escape" (Smith, 2012).

Furthermore, a child is more likely to become a soldier when a family member actively participates in a non-state armed group or becomes an orphan, as highlighted by Le Monde on March 31, 2017.

Regarding rehabilitation, Le Monde (July 23, 2015) reports about a ceremony in South Sudan for disarmament and social reintegration for child soldiers held in Pibor on February 10, 2015.

\subsubsection{Dangerous and Disorderly}

In 29 news, (35.80\%), child soldiers were portrayed as dangerous and disorderly, which is the second most found frame.

\section{Chart 2. Characteristics found in the frame of dangerous and disorderly (boys).}

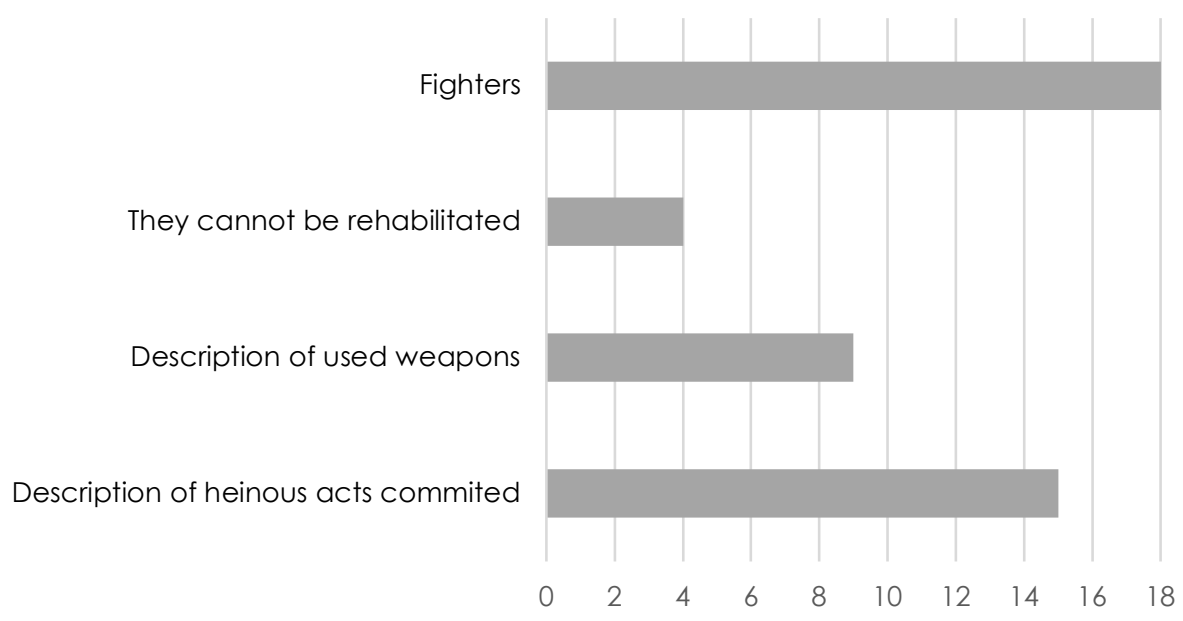

Source: Author created

In some articles, the atrocious acts they commit are emphasize, as reported by Le Monde (March 1, 201 1): "During attacks on the village, soldiers (referring to the soldiers of the Lord's Resistance Army), sometimes only over ten years old kidnap, rape, mutilate or massacre"(Lepidi, 2011).

In other cases, the descriptions are usually very graphic to shock the reader. Le Monde (November 21, 2013) reports that: "Adolescents are asked to cut a mother's chest or rape her sisters only to prove their bravery and obtain their weapons" (Vierge, 2013).

The weapons used by child soldiers to commit violent acts are also highlighted. The Guardian (December 5, 2013) reports that: "many of those involved in the latest violence are believed to be child soldiers, some reportedly armed with machetes, iron bars and other basic weaponry" (Smith and Willsher, 2013).

Le Monde (May 15, 2015) reports that 350 child soldiers have been released by one of the anti-Balaka commanders in the Central African Republic. Some children are as young as 8 years old in the anti-Balaka, where they serve as free labour, as spies or messengers. Those who are a little older fought and killed, using machetes or Kalashnikov rifles.

In some cases, articles go so far as to affirm that the acts they have committed are so terrible that there is no going back. There are children who will never be able to have a normal life again, they have become accustomed to violence as a way of life, reports Le Monde (May 15, 2015), referring to the act of liberation of 350 child soldiers in the Central African Republic:

Director Julien Bini explains that some children do not stay long (in demobilization and rehabilitation centres)... one of the boys threatened one of the girls to detonate a grenade at her house since she did not respond favourably to his sexual demands. (Fouchard, 2015). 


\subsubsection{The Hero}

Of all 81 articles, only 7 (8.64\%) articles were found in the frame of boy soldiers with the characteristic of heroes, giving them a voice.

\section{Graph 3. Characteristics found in the frame of heroes (boys)}

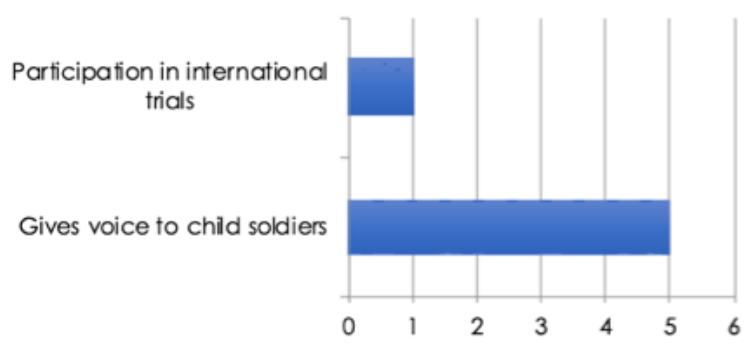

Source: Author created

They are given a voice in The Guardian (July 31, 2014) reporting that: "Former child soldiers and victims of war become ambassadors for peace in a nation where ethnic tensions have subsided" (Griffin, 2014).

They are also portrayed as heroes when they participate in international trials of the International Criminal Court as witnesses against commanders of non-state armed groups. The Guardian (March 14, 2012) reports that: "It is monumental when victims, including former child soldiers, are able to participate directly in the trial" (Cole, 2012).

\subsection{Representation of girl soldiers}

In general, girl soldiers are invisible in the media in comparison to boy soldiers. Girls were represented on 25 occasions; while boy soldiers appeared 91 times and girls were mostly portrayed in one of the 3 frames.

\subsubsection{The hapless victim}

17 articles (20.98\%) were found classifying girl soldiers as hapless victims. In 10 of those 17 they are portrayed as victims of sexual abuse and their recruitment is only mentioned in 7.

\section{Graph 4. Characteristics in the frame: The hapless victim (girls)}

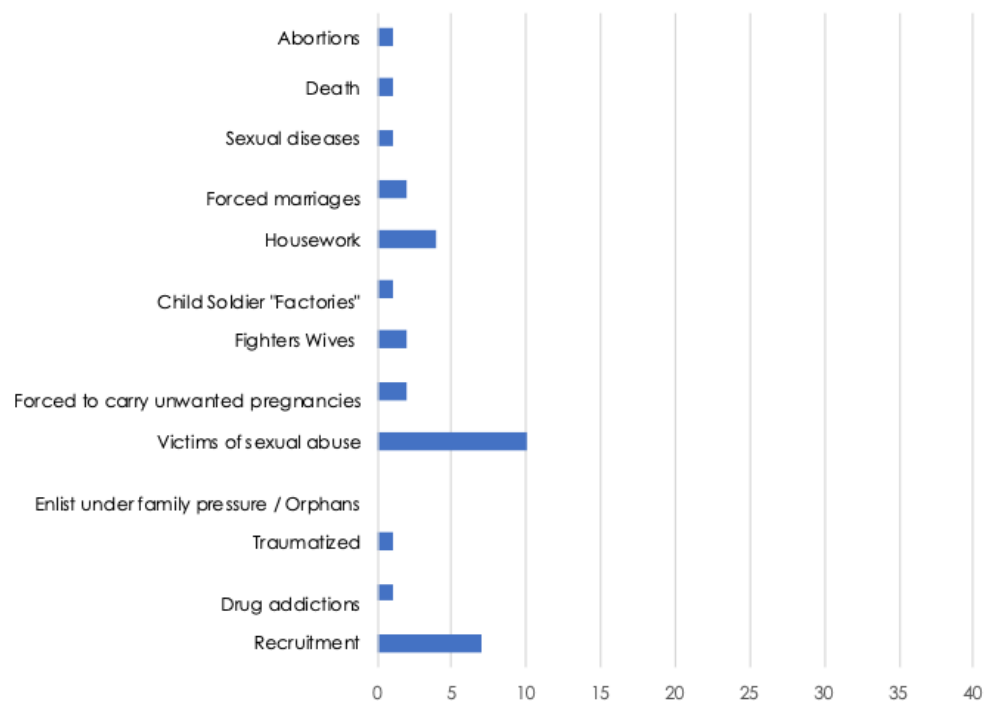

Source: Author created 
Girl soldiers are depicted as sex slaves, as women forced to carry unwanted pregnancies, wives of combatants, child soldier "factories," or doing housework, being raped and forced to marry combatants (The Guardian, August 2, 2015).

The media perpetuates established gender roles by characterizing girl soldiers, pointing out that girl soldiers are used for domestic work and sexual slavery. The Guardian (March 14, 2012) reports: "The use of girls in domestic work and the abuse of girls and women as sex slaves" (Cole, 2012).

They explain that boys are forced to fight, while girls are turned into sex slaves. Le Monde (March 1, 201 1): "When they capture young boys, the LRA (Lord's Resistance Army) transforms them into child soldiers. And the girls? They become sex slaves"(Lepidi, 2011). The LRA armed group operates in Central Africa, in the north of the Democratic Republic of the Congo, in South Sudan and in the east of the Central African Republic.

Le Monde (February 12, 2012) portrays girls in the category of victims: "The girls were, for the most part, used for sexual purposes" (Janier, 2012). The Guardian (March 8, 2012) in the same sense points out that: "They brainwash boys to fight for them, and turn girls into sex slaves and kill those who do not comply" (Curtis and McCarthy, 2012).

It was also reported that in other conflicts many women and girls are used as "child soldier factories" referring to how they are forced to have children who later become soldiers.

Le Monde (February 12, 2012) reports that in some conflicts, boy and girl soldiers are not on equal terms at the time of reintegration. According to Henri Leblanc, head of UNICEF programs in France, it is more difficult for girls, especially in West or Central Africa, due to the preconception that they have to remain virgins until marriage, since it is assumed that girls who participate in conflicts are no longer virgins. Furthermore, victims of sexual violence who become pregnant, in the specific case of Africa, are forced to have babies and when they return to their communities with children conceived and born in the rebel forces, they have even more problems being accepted due to cultural roles, where women have to be virgins until marriage (McKay, 2005).

Le Monde (December 6, 2016) reports that: "Children are kidnapped to become soldiers or 'wives" distributed to soldiers as spoils of war." In the midst of a powerful patriarchal structure, girls become men's property, they are used as a reward.

\subsubsection{Dangerous and Disorderly}

In the "dangerous and disorderly" frame, girl soldiers have little space in the analysed media. They appear in 6 articles (7.40\%) with this focus, all of which are found in the French newspaper Le Monde.

\section{Chart 5. Characteristics found in the frame: dangerous and disorderly (girls)}

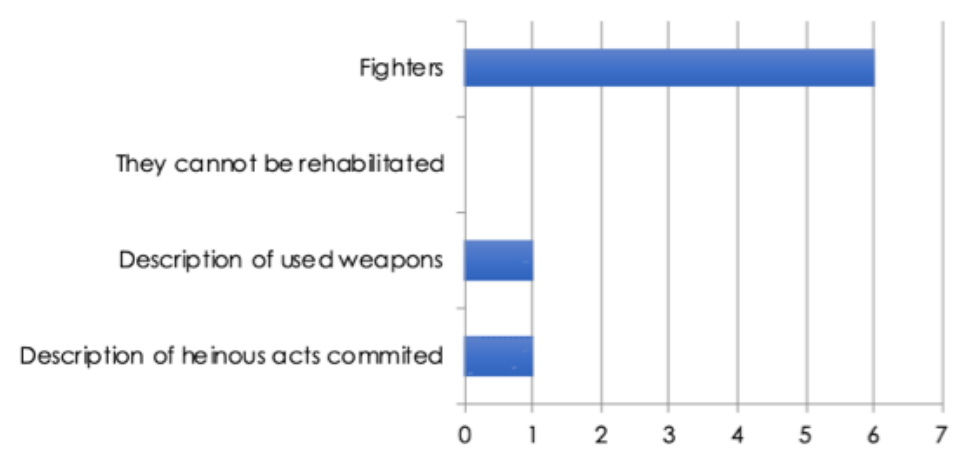

Source: Author created

In the same way that atrocious acts committed by boy soldiers are described, there is also such a description of girl soldiers, but in the context of fiction, that is, in movies, documentaries, novels... but not in the news. Le Monde (November 27, 2012) refers to this representation in the movie "War Witch": "Komona, 12 years old, was kidnapped, the guerrilla members forced her to murder her family." 
Girl soldiers sometimes engage with an armed group of their own choosing, because they believe in the cause they are fighting for. Le Monde (May 15, 2015) reports on one of these cases in the Central African Republic: "Maoussa is a 16-year-old girl who "voluntarily" joined the former rebel coalition Séléka... When you have an enemy in front of you, you have to shoot them down. You have no choice but to take them down. So we did it. To defend our country."

\subsubsection{The Hero}

The hero frame is found in only 2 articles (2.46\%) in Le Monde and none in The Guardian.

\section{Chart 6. Characteristics found in the frame of the hero (girls)}

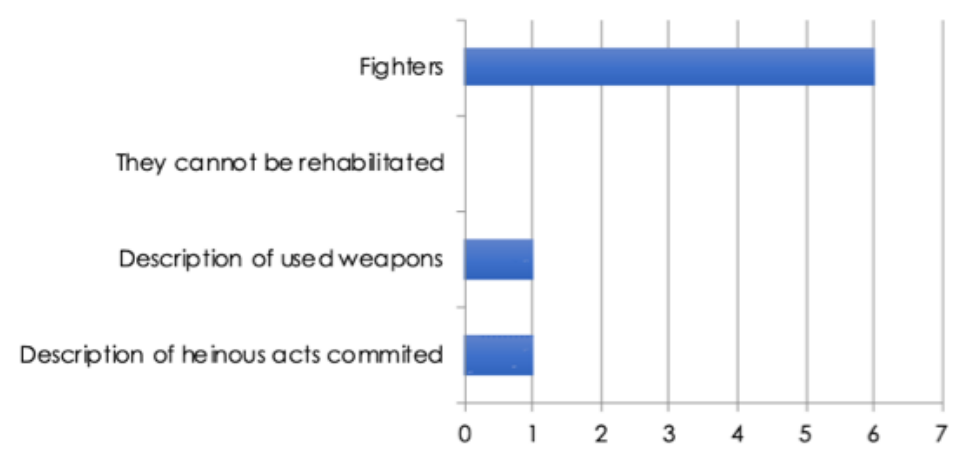

Source: Author created

Since Le Monde gave girl soldiers a voice in an interview, they were able to appear in the press as heroes. Both articles address a documentary on the lives of child soldiers titled "Wrong Elements" by director Jonathan Litell. Le Monde conducts an interview with two girl soldiers (and also two boys) who appear in the documentary.

As a conclusion of this section of results, we want to show in the following graph the comparison between boy and girl soldiers in the joint representation in the two newspapers (a total of 81 news articles) of the three analysed frames.

\section{Chart 7. Total number of news in Le Monde and The Guardian of child soldiers by frame}

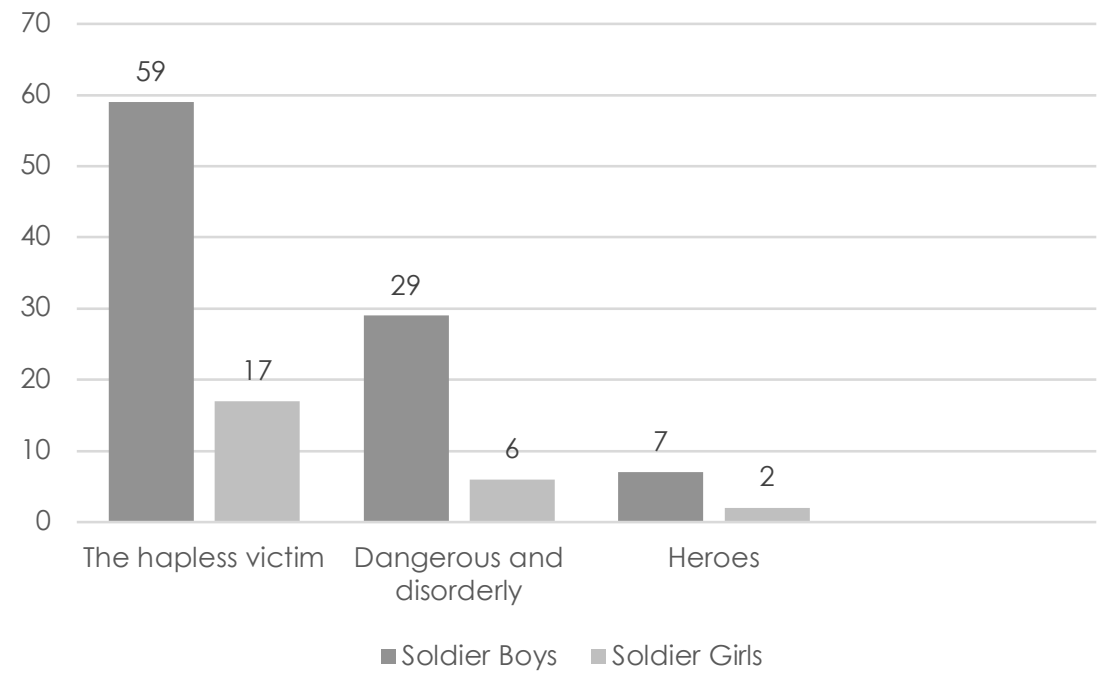

Source: Author created 
The imbalance in the media representation of boys and girls is evident, not only in terms of the number of appearances, but also and especially the way the news frames this problem, as will be discussed in further detail below as we discuss the results.

\subsection{Rehabilitation of girl soldiers}

Only 3 articles were found out of the 81 (3.70\%) that mentioned Disarmament, Demobilization and Reintegration (DDR) programs: 1 in The Guardian and 2 in Le Monde. This proves that there is little coverage of these programs, it also shows the specific difficulties in the rehabilitation process of girl soldiers due to gender inequality, which makes them even more invisible.

When girl soldiers are abused they will be stigmatized in their community, and because of this fear some of them decide not to go to Disarmament, Demobilization and Reintegration programs. Mazurana's (2005) describes this issue in her Geneva Call investigation, stating that most women and girls associated with armed opposition groups in Africa do not participate in official DDR programs. Among other reasons, she pointed to the fact that there is gender bias in the definition of combatant, as has also been pointed out when talking about the framing of girl soldiers as "dangerous and disorderly".

The Guardian (March 16, 2012) denounces how in some conflicts girl soldiers are often deliberately excluded and Le Monde (May 15, 2015) points out that many children go to demobilization centres to receive psychological help, however, in cases such as the Central African Republic there is no professional psychologists.

Despite being considered weaker in relation to boy soldiers, girls are forgotten by the Disarmament, Demobilization and Reintegration programs, as denounced by The Guardian (March 16, 2012): "Girls, who in some conflicts are a third of the total of child soldiers, they are often deliberately or inadvertently excluded from DDR programs" (Smith, 2012).

Many boys and girls go to demobilization centres for psychological help, however in the Central African Republic there is no professional psychologist. Le Monde (May 15, 2015) mentions Maoussa, a former child soldier from the Central African Republic who participated in the demobilization. "Maoussa is part of the 67 demobilized ex-Séléka youth" (Fouchard, 2015).

\section{Discussion}

The results of this research confirm the initial hypothesis about the existence of a gender bias in the discursive coverage of conflicts that use child soldiers. In the first place, the analysed media, Le Monde and The Guardian, when mentioning child soldiers refer to boys most of the time, 91 times compared to 25, thereby minimizing the presence of girl soldiers in conflicts, despite the fact that according to Böhmelt \& Haer (2018) girls can be up to $40 \%$ of child soldiers in recent African conflicts.

The results also agree with Denov (2012) that the media has been in charge of portraying these girls almost always within the context of "hapless victims", in the role of forced wives, victims of sexual slavery, kidnapping, not combatants. Le Monde and The Guardian represent girls like this up to 17 times, referring to topics such as the forced recruitment they suffer, trauma, rape and sexual abuse, forced marriages, unwanted pregnancies and abortions, being used as domestic slaves... But according to experts, most of the domestic chores are carried out by both boy and girl soldiers (Denov, 2010), this means the media is reproducing gender roles according to the Western concept.

Unlike the framing of boy soldiers as "hapless victims", there are no articles in this case about girl soldiers who are victims of drug addictions or who have enlisted due to family pressure or because they are orphans. However, Spellings (2008) affirms that there are girls who join the rebel groups due to propaganda and family pressure.

Le Monde and The Guardian portray girls as sex slaves and boys as fighters, like the second hypothesis of this research points out. In the frame of "dangerous and disorderly", the atrocious acts committed above all by boys are described and only boys appear with weapons, as combatants. This image reinforces the stereotype of gender role differentiation, spreading the myth that girls found in non-state armed groups do not have a military role (Fox, 2004). However, for example, in the Lord's Resistance Army almost all the kidnapped girls had military training (Coulter et al., 2008). Therefore, the above simplification that boys fight and girls are reduced to sex slaves is simply not true. In addition, horrific acts committed by a girl can only be found in one article in Le Monde (November 27, 2012), in the fictional sphere, in reference to the movie "War Witch". 
If it is in the realm of fiction, it seems that violent descriptions of girl soldiers are accepted by society. However, the reality is that when women fight they also commit acts of terror. In fact, in some conflicts women have been describes as crueller than men warriors (Coulter et al., 2008). This can cause bewilderment, since it contradicts traditional gender roles.

Like Entman (2004) says, the more congruent a frame is with the schemes that dominate cultural policy, the better it will be accepted by society. In this sense, the experiences of women in conflicts have been ignored until recently and the presence of girls in armed groups even more (Mckay, 2005).

As for the third analysed frame, "The Hero", it is very minor in both girls and boys in this case. Considering child soldiers heroes is perhaps closer to the western discourse of a happy ending. But at what point do they go from being victims to being considered perpetrators? As McKay (2005) points out, there is no such time line, they go from one characteristic to the other all the time. Giving them the label of victims or perpetrators fails to understand the complexity of changing roles, one moment they can be abused and the next they are the abusers.

Perhaps the most serious fact is the lack of a positive representation, not only as "hapless victim" or as "dangerous and disorderly", this creates a public opinion that these children cannot be rehabilitated, and therefore public agencies do not feel pressured to carry out more policies to eradicate child soldiers. By not showing cases of success, the hopes of ending the problem are significantly reduced.

This analysis also reveals the double victimization in the media coverage of girl soldiers, by depicting the situations they suffer as more important than condemning the perpetrators of violence against them or to report the rehabilitation programs, mentioned only in 3 of 81 articles.

A limitation of this study is undoubtedly the difficulty of extrapolating the results to the general media agenda, since in the international section of other countries -with no ties to a colonial past, such as the two chosen countries-, girl soldiers are not a topic, even the two armed conflicts themselves hardly have any space in the press. However, as a qualitative case study, we consider that the description shown in the news approaches reveals the same constructs in the media discourse regarding this forgotten topic within the always complex international information.

\section{Conclusions}

The objective of this investigation was to analyse how girl soldiers are represented in the media in two African armed conflicts where their use is very high and worrying: South Sudan and the Central African Republic. The results of the analysis in Le Monde and The Guardian show a clear gender bias, both in the total number of news and in selected approaches, when reporting on the presence of girls in these conflicts.

In the 81 analysed articles, the prevailing frame, for both boy and girl soldiers, is that of "hapless victim" (76 articles). But while boys appear in 59 articles, girls only appear in 17. Girls appear mainly as victims of sexual violence (12.3\% of the articles), victimizing them doubly when describing the abuse they are subjected to. On the other hand, although it is positive to focus on the aggressors, by making the non-state armed groups more visible, there is more focus on them than on their victims and there is a risk that the recruited minors, boys and girls, will disappear in the narrative or this problem, will be forgotten. It is also worrying that while the recruitment of boys is reported in 40 articles (49.38\%), the recruitment of girls is only reported in 7 articles $(8.64 \%)$, although several experts indicate that the recruitment figures are almost equivalent to the number of children.

As for the second frame, "dangerous and disorderly", it appears in a total of 35 articles as the second most frequent. However, there are gender differences again. Only 6 articles refer to girl soldiers in this frame. They hardly have space in the allegedly male role of combatants, $7.4 \%$ of the articles, while boys receive this frame in $49.3 \%$ of the cases. This is especially worrisome considering that when soldiers are disarmed, demobilized and reintegrated, boys have priority over girls because of the social image that exists regarding the participation of girls in conflicts, and that the media has contributed to emphasize the representation of girl soldiers who do not fight.

In the third frame of "heroes", girl soldiers appear in only 2 of the articles, as do the boy soldiers, who also have a low representation, with only 7 articles. The lack of positive media images, beyond the frame of "hapless victim" or "dangerous and disorderly", sends a message to public opinion that nothing more can be done, and therefore public offices do not feel pressured to carry out more Disarmament, Demobilization and Reintegration (DDR) programs. There is no mention of girl soldiers participating in international trials. This 
means losing the opportunity of a great showcase facing public opinion when it comes to making their problems visible.

Girl soldier rehabilitation is barely present or rather is almost nil in the analysed media. Only 3 articles talk about it, despite the serious repercussions that this issue has for girls, who again suffer discrimination based on their gender.

The Guardian's representation of girl soldiers in the conflict in South Sudan is reduced to presenting them as "hapless victim", without any reference to either "dangerous and disorderly" or "hero" frames. In this sense, Le Monde makes the girl soldiers of the Central African Republic more visible by showing more of their complex reality.

The media should give child soldiers who have managed to return to civilian life more coverage. The stories of overcoming these situations are important for politicians to view the existing failures due to gender bias that make reintegration even more difficult in the case of girl soldiers and therefore acknowledge the importance of creating adequate rehabilitation policies and programs.

The Guardian and Le Monde, sometimes generalize speaking of the African conflicts that were analysed, from a Western perspective. Instead, they should try to portray the situation of girl soldiers in a more adjusted way so that the policies created for their protection, reintegration, and demobilization go more according to their reality.

This research, although presenting relevant results, is limited by the lack of international and intercultural studies, highlighted by the fact that only two western newspapers had enough information to be cited. For future research, it would be interesting to analyse the coverage and representation of the problem of girl soldiers in newspapers in South Sudan and in the Central African Republic to compare if there are differences between Western newspapers and their African counterparts regarding girl soldiers.

\section{Acknowledgement}

Translator: Laura Yvonne Patiño.

\section{References}

[1] Andsager, J. (2000). How Interest Groups Attempt To Shape Public Opinion with Competing New Frames. Journalism and Mass Communication Quaterly, 77(3), 577-592. http://doi.org/ctxwjx

[2] Baas, S. (2011). From civilians to soldiers and from soldiers to civilians: A micro-approach to disarmament, demobilization, and reintegration (DDR) in Sudan. (Doctoral thesis) University of Amsterdam. Netherlands.

[3] Blattman, C. \& Annan, J. (2010). The consequences of child soldiering. The Review of Economics and Statistics, 92(4), 882-898. http://doi.org/c7dns5

[4] Böhmelt, T. \& Haer, R. (2018). Girl soldiering in rebel groups, 1989-2013: Introducing a new dataset. Journal of Peace Research, 55(3), 395-403. http://doi.org/gdj272

[5] Brownell, G. \& Praetorius R.T. (2017). Experiences of former child soldiers in Africa: A qualitative interpretive meta-synthesis. International Social Work, 60(2), 452-469. http://doi.org/f9x6aj

[6] Carlsen, C. (2013). The voices of the invisible girls: Reintegration of former female child soldiers in Burundi. (Tesis de Máster). Agder University . Norway.

[7] Child Soldiers International (2016). Des milliers des vies a reparer. Disponible en shorturl.at/cjmvT

[8] Child Soldiers International (2018). In pictures: Meeting South Sudan's returning girl. Available on shorturl.at/GHIQ0

[9] Cole, A. (March 14, 2012). Lubanga judgment marks milestone in the path towards accountability. The Guardian. Available on shorturl.at/bvEG9

[10] Cotorcea, S. (2017). Reintegrating girls and boys formerly associated with armed forces and armed groups: A case study from Central African Republic (CAR). Save the Children.

[11] Coulter, C.; Persson, M. \& Utas, M. (2008). Young Female Fighters in African Wars: Conflict and its Consequences. NAI Policy Dialogue. Nordic Africa Institute. Available on shorturl.at/fasF1 
[12] Curtis, P. \& McCarthy, T. (March 8, 2012). Kony 2012: what's the real story?. The Guardian. Available on shorturl.at/amMQZ

[13] Denov, M. (2008). Girl soldiers and Human Rights: Lessons from Angola, Mozambique, Sierra Leone, and Northern Uganda. International Journal of Human Rights, (12), 81 1-833. http://doi.org/cgx2fz

[14] Denov, M. (2010). Child Soldiers: Sierra Leone's Revolutionary United Front. Cambridge: Cambridge University Press.

[15] Denov, M. (2012). Child Soldiers and Iconography: Portrayals and (Mis)representations. Children \& Society, 26(4), 280-292. http://doi.org/bpr6zz

[16] Ensor, M. (2012). Child Soldiers and Youth Citizens in South Sudan's Armed Conflict. Peace Review, 24(3), 276-283. http://doi.org/dqq4

[17] Entman, R. (2004). Projections of Power: Framing News, Public Opinion, and U.S. Foreign Policy.

Chicago: University of Chicago Press. http://doi.org/dqq5

[18] Fairclough, N. (1992-1993). Discourse and Social Change. Cambridge: Polity Press.

[19] Fouchard, A. (May 15, 2015). Plus de 350 Enfants Soldats Libérés en Centrafrique. Le Monde. Available on shorturl.at/ampJY

[20] Fox, M. J. (2004). Girl Soldiers: Human Security and Gendered Insecurity. Security Dialogue, 35(4), 465479. http://doi.org/dkwjqd

[21] Gamson, W. \& Modigliani, A. (1989). Media Discours and Public Opinion on Nuclear Power: A Constructionist Approach. American Journal of Sociology, 95(1), 1-37. http://doi.org/cwz3w8

[22] González-Aldea, P. (2014). El periodismo internacional en la era digital. Santa Cruz de Tenerife: Ediciones Idea.

[23] Griffin, J. (July 31, 2014). Killers to healers: training Burundi's youth to choose peace. The Guardian. Available on shorturl.at/DTZ89

[24] Honwana, A. (2006). Child Soldiers in Africa. Philadelphia: University of Pennsylvania Press.

[25] IRIN. (April 12, 2012). DRC: Thorny Issue of Reparations for Lubanga's Victims. The Guardian. Available on shorturl.at/oKLWY

[26] Janier, A. (Februrary 12, 2012). Les Enfants Soldats Face au Défi de la Réinsertion. Le Monde. Available on shorturl.at/uzOV4

[27] McCombs, M. \& Shaw, D. (1993). The Evolution of Agenda-Setting Research: Twenty-Five Years in the Marketplace of Ideas. Journal of Communication, 43(2), 58-67. http://doi.org/chasbm

[28] Macmillan, L. (2009). The Child Soldier in North-South Relations. International Political Sociology, (3), 36-52. http://doi.org/cvn3×5

[29] McKay, S. (1998). The Effects of Armed Conflict on Girls and Women. Peace and Conflict: Journal of Peace Psychology, 4(4), 381-392. http://doi.org/bwh93w

[30] McKay, S. (2005). Girls as "Weapons of terror" in Northern Uganda and Sierra Leonean Rebel Fighting Forces. Studies in Conflict \& Terrorism, 28(5), 385-397. http://doi.org/fws7xr

[31] Mazurana, D. (2005). Women in Armed Opposition Groups in Africa and the Promotion of International Humanitarian Law and Human Rights, PSIO, Geneva Call. Available on shorturl.at/HVY19

[32] Mazurana, D. \& McKay, S. (2001). Child soldiers: What about the girls?. Bulletin of the Atomic Scientists, 57(1), 30-35. http://doi.org/dmpj2h

[33] Mazurana, D.; McKay, S.; Carlson, K. \& Kasper, J. (2002). Girls in Fighting Forces and Groups: Their Recruitment, Participation, Demobilization, and Reintegration. Peace and Conflict: Journal of Peace Psychology, 8(2), 97-123. http://doi.org/b4d6j8

[34] Naciones Unidas, Asamblea General. (1989). Convención sobre los Derechos del Niño, 44/25, (20 de noviembre, 1989). Available on shorturl.at/fgjt 1

[35] Naciones Unidas, Asamblea General (1996). The Impact of Armed Conflict on Children: informe del experto del Secretario-General Sra. Machel Graça, A/51/306 (August 26, 1996). Available on shorturl.at/IzG14 
[36] Naciones Unidas, Asamblea General (2002). Protocolo facultativo de la convención sobre los Derechos del Niño relativo a la participación de niños en los conflictos armados, A/RES/54/263 (February 12, 2002). Available on shorturl.at/cvwzT

[37] Naciones Unidas (2018). Los niños y los conflictos armados: informe por el Secretario-General, A/72/865 - S/2018/465 (May 16, 2018). Available on shorturl.at/gwNWZ

[38] Office of the Special Representative of the Secretary-General for Children and Armed Conflict (2018). Action Plan to Protect Children Signed in the Central African Republic. New York. Available on shorturl.at/xFKQ4

[39] Quian, A. y Elías, C. (2018). Estrategias y razones del impacto de WikiLeaks en la opinión pública mundial. Revista Española de Investigaciones Sociológicas, 162(91), 91-110. http://doi.org/dqq6

[40] Rosen, D. (2005). Armies of the Young: Child Soldiers in War and Terrorism. New Brunswick, NJ: Rutgers University Press.

[41] Smith, D. \& Willsher, K. (December 5, 2013). Clashes in Central African Republic as UN authorises French Intervention. The Guardian. Available on shorturl.at/ntVWX

[42] Solman, P. \& Henderson, L. (2019). Flood disasters in the United Kingdom and India: A critical discourse analysis of media reporting. Journalism, 20(12), 1648-1664. http://doi.org/dqq7

[43] Spellings, C.R. (2008). Scratching the Surface: A Comparison of Girl Soldiers From Three Geographic Regions of the World. International Education, 38(1), 21-39.

[44] Tassava, J. (2017). The Portrayal of Child soldiers in Documentaries and Hollywood Film. Butler Journal of Undergraduate Research, (3), 158-171.

[45] Thomas, C.G. (2018). Secession and Separatism in Modern Africa. In: Shanguhiya, M., Falola T. (eds). The Palgrave Handbook of African Colonial and Postcolonial History (pp. 729-757). New York, United States: Palgrave Macmillan.

[46] United Nations Youth (2015). 4 out of 10 child Soldiers are Girls. Available on shorturl.at/juNPU

[47] Van Dijk, T. (2008). Discourse and Context: A Sociocognitive Approach. Cambridge: Cambridge University Press.

[48] Vierge, R. (21 de noviembre, 2013). Le Dr Mukwege, Infatigable Défenseur des Femmes Violées en RDC, Lauréat de la Fondation Chirac. Le Monde. Available on shorturl.at/oDSVZ

[49] Wessels, M. (2006). Child Soldiers: From Violence to Protection. Cambridge, MA: Harvard University Press.

[50] Wodak, R. \& Meyer, M. (2001). Methods of Critical Discourse Analysis. London: SAGE Publications.

\section{Revista MEDITERRÁNEA de Comunicación MEDITERRANEAN Journal of Communication}

